\title{
Natural Forest Fragmentation Evaluation in the Campos Gerais Region, Southern Brazil
}

\author{
Rosemeri Segecin Moro*, Elisana Milan
}

Graduate Studies in Geography, Ponta Grossa State University, Brazil

Copyright $\bigcirc 2016$ by authors, all rights reserved. Authors agree that this article remains permanently open access under the terms of the Creative Commons Attribution License 4.0 International License

\begin{abstract}
In the Campos Gerais region a mixed Araucaria forest has been fragmented mainly as a result of natural processes related to Quaternary climatic fluctuations. Yet these fragmented grassland patterns in South Brazil have not yet been settled; therefore, two preserved areas, Vila Velha and Guartelá State Parks, were selected to determine the region's current natural forest patterns. Mapping reveals a highly fragmented landscape on a fractal dimension. It was observed that most of the patches were smaller than 10 ha ( $90.3 \%$ of the total number of patches) and very few were larger than 100 ha $(2.7 \%)$. The smaller patches were in simple regular shape, and exhibited increased edge effects. However, their sum makes up a small representation of the total area. The largest patch was over 100 ha, and was more complex and irregular in shape. The connectivity between all patches was considered good once they were at least $50 \mathrm{~m}$ apart. Several islets acted as "stepping-stone" corridors. From the ecological perspective, large patches can act as source areas and maintain biodiversity, whereas small patches can act as stepping-stones or migration corridors, refuges, or provide sites for nucleation. This natural pattern could act as a reference for further study in landscape restoration. This analysis discourages government efforts to increase hydroelectrical expansion, in Campos Gerais, as infrastructure will be built across the gorges and canyons that support the most demanding and sensitive species. Furthermore, public policies requiring landowners to protect small forest patches within their farmlands are needed because they are extremely important for maintaining these landscape connections.
\end{abstract}

Keywords Landscape Structure, Mixed Araucaria forest, Grassland-forest Ecotone

\section{Introduction}

The Campos Gerais region, in southern Brazil, presents a unique landscape of great ecotonal relevance where the spatial arrangement of forests and grasslands is the result of the Late Quaternary (0.5-1 million years ago) climatic fluctuations [1]. These ecosystems are within the Mata Atlantica Domain, which is one of the global biodiversity hotspots [2] and they have been identified as conservation priorities in south Brazil [3, 4].

In the last decade, renewed discussions about this ecotone maintenance focused mainly on the relationship among grassland fire and grazing related to species distribution, aside from paleoclimate drivers $[5,6]$. Yet fragmented grasslands patterns in South Brazil are not settled.

This paper intends to elucidate the current spatial configuration of landscape related to natural rather than anthropogenic environmental dynamics, in order to depict patterns needed for further analysis of disturbances.

\section{Methods}

Two well-preserved areas typical to the Mata Atlantica Domain (Vila Velha and Guartelá State Park) were sampled in order to depict the natural fragmentation patterns (Figures 1,2). Both study areas are classified as Cfb Koeppen climate types at 800-1,170 m.a.s.l. in a mountainous relief. These protected areas were not settled until 70 years ago. Prior to this, the entire Campos Gerais region experienced intensive logging; therefore, the forests are no longer primary. As such, it is expected that these areas should present a combination of natural vegetation recovery as well as some undisturbed remnants.

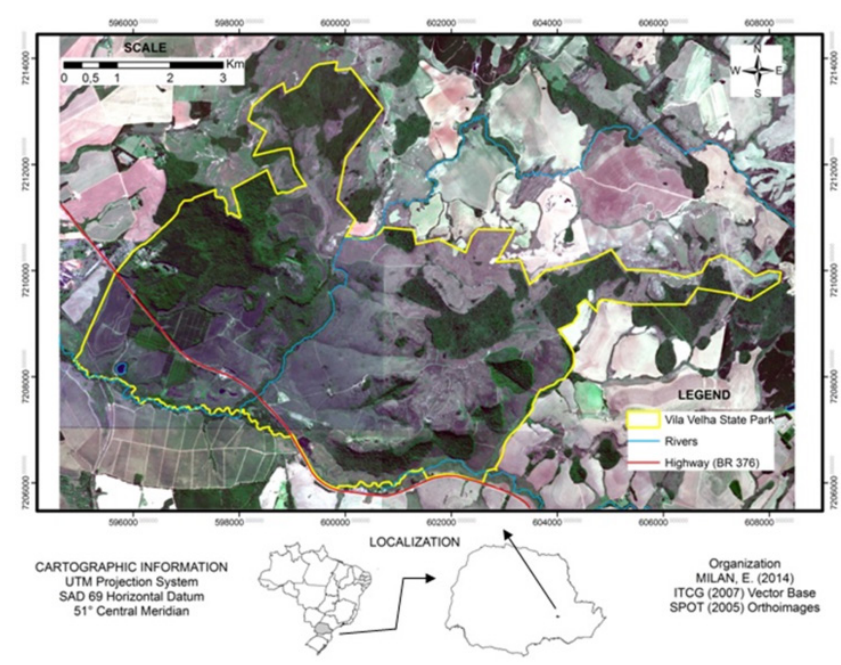

Figure 1. Vila Velha State Park location, Ponta Grossa, PR, Brazil. 


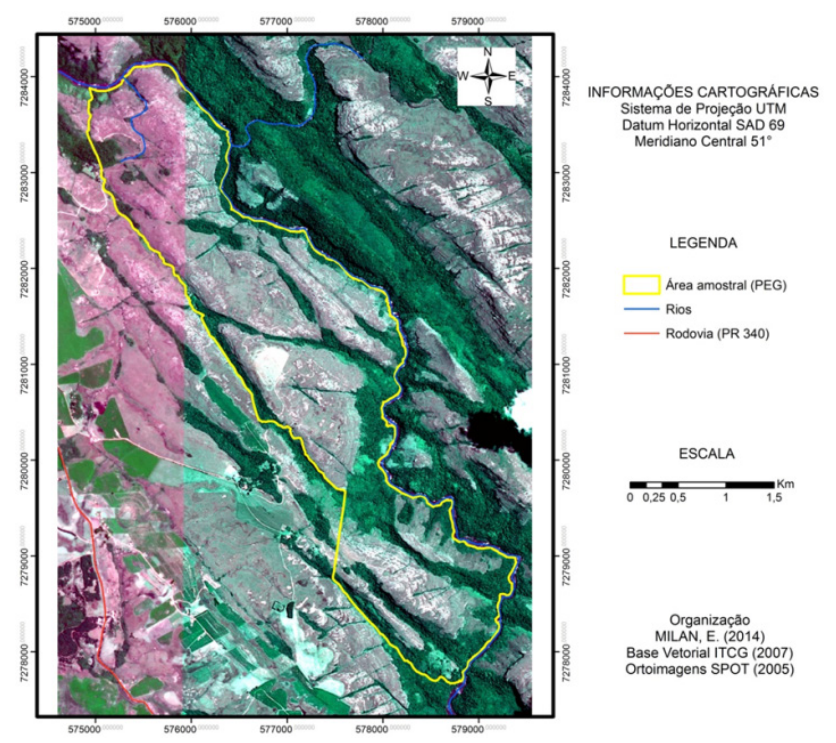

Figure 2. Guartelá State Park location, Tibagi, PR, Brazil.

A 22 SPOT 5 ortho images mosaic with $5 \mathrm{~m}$ resolution was employed and images processed with Envi 4.7 and Arc Gis 9.3 software. Data were collected from a vector map consisting of two classes: forest-habitat patches (1), and non-habitat (0). It is assumed that this is a simplification of the real landscape since other elements, such as urban areas, roads, and water were previously classified and their values were considered negligible $[7,8]$. The files were converted from vector (.shp) to raster (.tiff) and text (.asc) in order to analyze the landscape composition in the MSPA module using Guidos 1.3 software [9], and to calculate landscape metrics in Fragstats 2.0 [10].

Buffers were considered to be a $50 \mathrm{~m}$ extension to the edge [11-14]. Therefore, landscape elements classified were matrix (grassland) and patches (forest). Also, landscape elements were delimited such as core, edge, corridors, branches, loops, and islets [15].

The following landscape scale indicators were selected:

AREA (total area in hectares), CA (class area of both matrix and patches, in hectares), \%LAND (percent of each class in the landscape), NP (patch number), SHDI (Shannon diversity index), SHEI (Shannon uniformity index), SHAPE (patch shape index), FRACT (fractal dimension), CORE (patch nucleous area assuming a $50 \mathrm{~m}$ edge), CONNECT (connectivity index), PROX (proximity index), and NND (next neighbor distance).

The search radius of $50 \mathrm{~m}$ followed Barros \& Moro [16] with the average distances of local dispersion (pollination and seed dispersal) within the Mixed Araucaria Forest.

Parametric and non-parametric analysis comprised Chi-square test and ANOVA-One Way analysis as well as Principal Component Analysis performed by the software past [17].

\section{Results and Discussion}

As shown in Table 1, data pointed to a similar proportion for mixed Araucaria forest in the parks - almost 34\% (\%LAND) regardless of differences in their size (AREA). The patch area is a very important parameter for explaining specific richness variations and therefore it should be noted that almost $90 \%$ of the patches are smaller than $10 \mathrm{ha}$, which corresponds to less than $10 \%$ of the total landscape. In fact, the median showed that half of the forest patches are even smaller than 1 ha. Only $2.7 \%$ of patches were larger than 100 ha, with only nine patches being categorized as 'source' areas, comprising $10-20 \%$ of the entire landscape. The smaller the patch is, the greater is the influence of external factors, which affect the internal processes of the ecosystem. Small patches tend to bear reduced populations of certain species, which often can affect the sustainability of the species in question [18]. Nevertheless, while large patches are important in maintaining biodiversity and ecological processes on a large scale, small remnants play a crucial role in the landscape. They may act as connecting elements between large areas, as stepping-stone corridors [19], promoting an increase in the level of heterogeneity in the matrix, and acting as a refuge for species requiring particular environments that only occur locally [20]. This is especially true for heterogeneous naturally fragmented landscapes [15].

SHDI measures landscape heterogeneity, ranging from ' 0 ' for homogeneous landscapes, to ' 1 ', for heterogeneous ones (with several size classes). In both studied parks, SHDI on a landscape scale showed values close to 0.60 , which indicated low to moderate landscape diversity. In non-protected areas in Campos Gerais, the researchers Moro, Nanuncio \& Dalazoana [21] found SHDI values ranging from 0.68 to 0.99. According to Metzger [22], more diversified landscapes promote the existence of generalist species, indirectly increasing the mortality of species susceptible to fragmentation. On the other hand, landscapes that are more homogeneous favor species that require large areas for habitat, as they are sensitive to interior fragmentation. Regarding homogeneity, SHEI varies from ' 0 ' (great differences among areas) to ' 1 ' (all areas possess same class type). In the studied areas, values close to 0.90 reinforced the relatively high homogeneity that encourages biological flows among the species that inhabit the region. Moro, Nanuncio \& Dalazoana [21] found a moderate 0.62 to 0.73 SHEI for the non-protected areas. This indicates that the same authors [21] found that protected and non-protected areas were significantly different in diversity and uniformity $(\mathrm{p}<0.06)$.

SHAPE index ranges from ' 1 ', denoting small and rounded patches, to ' 4 ', denoting the presence of more complex shapes, mainly linear ones. This study indicated that most of the parks' patches were a categorical SHAPE ' 2 ' ( $81 \%$ in Guartelá and $76 \%$ in Vila Velha). Moro, Nanuncio \& Dalazoana [21], and Moro, Milan \& Moro [8] assigned SHAPE ' 2 ' to Campos Gerais, as a result of the geomorphological structural control due to i) accompanying riparian areas and structural lineaments inducing a higher shapes index; ii) enclosures of tree vegetation created small portions of fertile and deeper soils with higher water 
potential, which set isodiametric patches. Fractal dimensions reinforced the predominant SHAPE once the patches in the landscape were already distributed as fractals (FRACT = $1.0-1.3$ ). More than $70 \%$ of the patches were between 10 and $100 \mathrm{~m}$ from the nearest forest patch, yet Vila Velha had a greater number of patches in the distance class between 100 and $500 \mathrm{~m}(\mathrm{p}=0.86)$. The medians indicate that indeed half of the patches were located less than $50 \mathrm{~m}$ away from the next patch. This proximity does promote structural and functional connectivity, although it depends on other factors such as the permeability of the matrix, the ability of percolation, relief, the ability of the species to respond to these structural features, and other aspects [22].

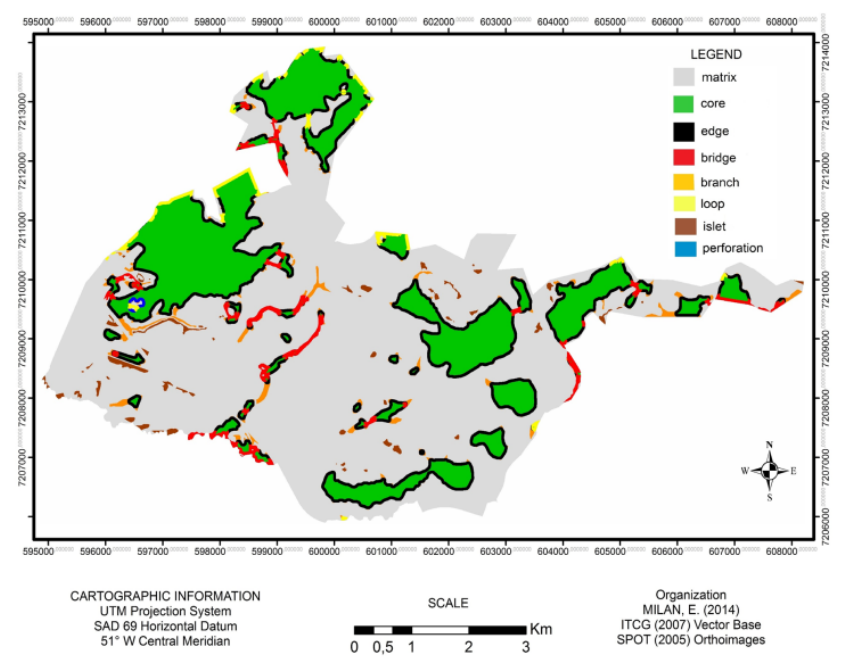

Figure 3. Landscape elements in Vila Velha State Park (PEVV).

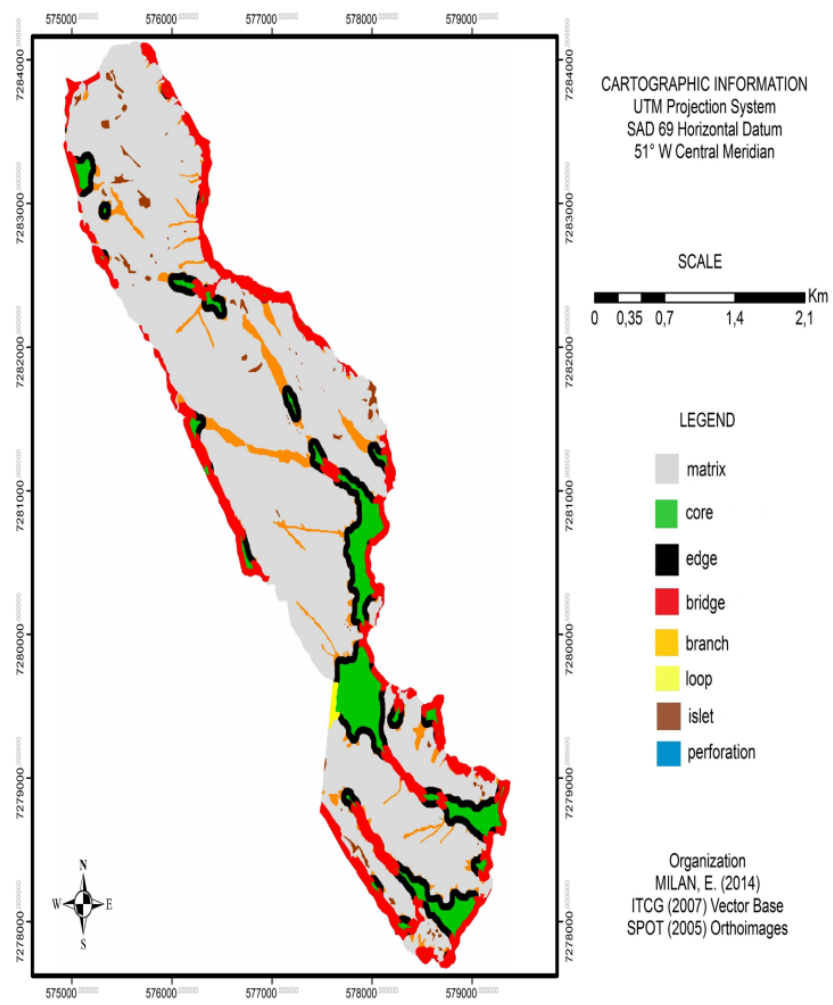

Figure 4. Landscape elements in Guartelá State Park (PEG).
The PROX index expresses a hypothetical availability of habitat to any species. According to Vila Velha and Guartelá, within a $50 \mathrm{~m}$ radius search, half of the patches were respectively up to 20 and $36 \mathrm{~m}$ within proximity of a neighboring parcel (as estimated by the median). The CONNECT proportion revealed that there are very few connectable areas $(0.89$ to $2.0 \%)$ in a $50 \mathrm{~m}$ radius. Barros \& Moro [16] state that there is a lack of sensitive data when it comes to pollen and seed dispersal distances within the Mata Atlantica Domain; even so, four key species indicated that the connections between Guartelá and Vila Velha patches are possible for some local species. Analyzing core and edge areas, the fragmented spatial configuration of the patches is clear (Figures 3, 4).

The patch density per 100 ha does not differ among the sites $(\mathrm{p}=0.008)$. It is remarkable that the Guartelá Park edge dimensions did exceed the core area with what could be credited to the structural control of the relief, as $99.5 \%$ of the variance could be explained by the first axis of a Principal Component Analysis. Guartelá showed a higher proportion of corridors (12.6\%) while false-corridors (branches and loops) were numerous but less than $5 \%$ of the total area of the two landscapes. It should be noted that branches and loops do not connect two areas. Islets deserve more attention given that they possibly fulfill the function of stepping-stones, facilitating the movement and gene flow across the bigger landscape for many species $[19,20]$ or may still be starting the process of nucleation over the grassland. In all areas, the percentage of islets was small, reaching not even $3 \%$, but they were numerous and, for the most part, near larger patches.

Table 1. Landscape elements and related metrics in the Mixed Araucaria Forest patches.

\begin{tabular}{|c|c|c|}
\hline $\begin{array}{c}\text { Considered } \\
\text { metrics }\end{array}$ & $\begin{array}{c}\text { Guartelá (2433' S; } \\
\left.50^{\circ} 15^{\prime} \mathrm{W}\right)\end{array}$ & $\begin{array}{c}\text { Vila Velha }\left(25^{\circ} 14^{\prime} \mathrm{S}\right. \\
\left.50^{\circ} 00^{\prime} \mathrm{W}\right)\end{array}$ \\
\hline AREA (ha) & 798.97 & $3,803.28$ \\
\hline $\begin{array}{c}\text { Grassland } \\
\text { matrix (\%) }\end{array}$ & 66.15 & 67.05 \\
\hline $\begin{array}{c}\text { Forest } \\
\text { patches }(\%)\end{array}$ & 33.85 & 32.95 \\
\hline NP & 96 & 89 \\
\hline $\begin{array}{c}\text { Mean - } \\
\text { median patch } \\
\text { area (ha) }\end{array}$ & $2.81-0.11$ & $15.37-0.93$ \\
\hline SHDI & 0.62 & 0.63 \\
\hline SHEI & 0.89 & 0.91 \\
\hline $\begin{array}{c}\text { Mean - } \\
\text { median NND } \\
(\mathrm{m})\end{array}$ & $32.97-25.00$ & $72.28-44.72$ \\
\hline $\begin{array}{c}\text { Mean - } \\
\text { median } \\
\text { PROX }(\mathrm{m})^{*}\end{array}$ & $731.08-35.78$ & $1,129.06-20.0$ \\
\hline $\begin{array}{c}\text { CONNECT } \\
(\%)^{*}\end{array}$ & 1.95 & 0.89 \\
\hline Core $(\%)$ & 6.33 & 19.97 \\
\hline Edge $(\%)$ & 6.86 & 7.51 \\
\hline Corridor (\%) & 12.56 & 2.03 \\
\hline Branch (\%) & 4.38 & 1.31 \\
\hline Loop (\%) & 0.21 & 1.03 \\
\hline Islet (\%) & 1.09 & 1.02 \\
\hline
\end{tabular}

*search radius of $50 \mathrm{~m}$. 


\section{Conclusions}

The natural forest landscape of Campos Gerais is quite fragmented and comprises no more than $30-40 \%$ of the area, allowing for ecotones with the surrounding grasslands. Small forest patches predominate the landscape and their relatively small core areas decrease the chances of maintaining high biodiversity. These patches, however, act as stepping-stones, refuges, or sources of forest nucleation, thus ensuring biological fluxes. The larger patches are linear in general, riparian or inside lineaments and canyons. While riparian patches act as corridors, the patches inside canyons play more of a refuge role to various species. This relatively homogeneous landscape favors species that need large habitat areas, as these types of species are sensitive to interior fragmentation. Thus, we recommend maintaining or even increasing the size of the major protected areas instead of increasing their number.

Regarding the proximity among the patches within the hypothetical radius analyzed, most of the patches were found to be less than $50 \mathrm{~m}$ from a neighboring patch, facilitating flows along the matrix. Despite the lack of reliable data about pollen and seed dispersal distances in the mixed Araucaria Forest, some key species data indicated that the connection among patches within each sampled area is possible.

Despite natural forests being highly fragmented, the patches were close enough to provide opportunity for a multiplicity of connections within the grassland matrix; we, therefore, conclude that this forested landscape is functionally connected rather than structurally.

Forest fragmentation was driven mainly by paleoclimate conditions and past deforestation seems to only be a minor factor in the current distribution patches as evidenced by the 70-years of preserved area dynamics.

Thus this analysis discourages government efforts to increase the hydro-electricity supply in Campos Gerais, as infrastructure will be built across the gorges and canyons that support the most demanding and sensitive species. Furthermore, public policies should focus on landowners protecting small forest patches within their farmlands as these patches are extremely important for ecosystem connections.

\section{Acknowledgements}

We are very grateful to the Brazilian Government for supporting this research in protected areas in the Paraná State and to CAPES for the second author PhD grant in progress.

\section{REFERENCES}

[1] H. Behling. Late Quaternary vegetation, climate and fire history in the Araucaria forest and campos region from Serra Campos Gerais (Paraná), South Brazil, Review of Paleobotany and Palynology, Vol.97, 109-121, 1997.

[2] R.A. Myers, C.G. Mittermeier, G.A.B. Mittermeier, J. Kent. Biodiversity hotspots for conservation priorities, Nature, No.403, 853-858, 2000.

[3] J.R. Grando, M. Bornschein, R.S. Moro, M.B. do Carmo, I.F. Barbola, R.C. Tardivo. Campos Gerais: Norte e Sul. In: D.N. Bilenca, F. Minarro (eds.): Identificación de áreas valiosas de pastizal (AVPs) em las Pampas y campos de Argentina, Uruguay y sur de Brasil. FVSA, Buenos Aires, 2004.

[4] MMA/SBF. Biodiversidade Brasileira: avaliação e identificação de áreas prioritárias para conservação, utilização sustentável e repartição de benefícios da biodiversidade brasileira. Brasília, 2007.

[5] H. Behling, V.D. Pillar. Late Quaternary vegetation, biodiversity and fire dynamics on the southern Brazilian highland and their implication for conservation and management of modern Araucaria forest and grassland ecosystems, Philosophical Transactions of the Royal Society B, Vol. 362, 243-251, 2007.

[6] H. Behling, V.D. Pillar, S.C. Miuller, G.E. Overbeck. Late Holocene fire history in a forest-grassland mosaic in southern Brazil: implications for conservation. Applied Vegetation Science, Vol. 10, 81-90, 2007.

[7] A.F. Ramos, A.C. Santana, C.C. Prieto, L.F. Matias. Mapeamento do uso da terra nos Campos Gerais. In: M.S. Melo, R.S. Moro, G.B. Guimarães (eds.) Patrimônio natural dos Campos Gerais do Paraná, EDUEPG, Ponta Grossa, 2007. cap. 7, p.95-92.

[8] R.S. Moro, E. Milan, R.F. Moro. Biodiversidade do estrato herbáceo-arbustivo em capões no Parque Estadual de Vila Velha, Ponta Grossa, PR, Biodiversidade Brasileira, Vol.2, 102-112, 2012.

[9] P. Vogt. GUIDOS version 1.3: User Guide. Joint Research Centre (JRC), 2010.

[10] K. McGarigal, K., B. Marks. Fragstats: Spatial Pattern Analysis Program for Quantifying Landscape Structure. USDA - United States Department of Agriculture. General Technical Report. Pacific Nortwest Research Station 351, Portland, 1995.

[11] R. Baldissera, G. Ganade. Predação de sementes ao longo de uma borda de Floresta Ombrófila Mista e pastagem, Acta Botanica Brasilica, Vol. 19, 161-165, 2005.

[12] S.B. Fontoura, G. Ganade, J. Larocca. Changes in plant community diversity and composition across an edge between Araucaria forest and pasture in South Brazil, Revista Brasileira de Botanica, Vol.29, 79-91, 2006.

[13] E. Malchow, A.B. Koehler, S. Péllico Netto, S. Efeito de borda em um trecho da Floresta Ombrófila Mista, em Fazenda Rio Grande, PR, Revista Acadêmica, Vol.4, 85-94, 2006.

[14] R.S. Moro, E. Milan, R.F. Moro, B.C. do Carmo, A.P. Protachevicz. Definição de borda a partir da composição de espécies da Floresta Ombrófila na Reserva Biológica das Araucárias, Paraná, Brasil, Proceedings of the XI ENANPEGE, UNESP-Presidente Prudente, 1-14, 2015.

[15] M.G. Turner, R.H. Gardner, R.V. O’Neill. Landscape Ecology: 
in theory and practice. Springer, New York, 2001.

[16] K, F. de Barros, R.S. Moro. Conectividade estrutural entre a Floresta Nacional de Piraí do Sul e seu entorno, Paraná, Brasil, Geoingá, Vol.7, 210-233, 2015.

[17] Ø. Hammer, D.A.T. Harper, P.D. Ryan. PAST: Paleontological Statistics Software Package for Education and Data Analysis. Palaeontologia Electronica, Vol.4, 1-9. 2001.

[18] V. Kapos. Effects of isolation on the water status of forest patches in the Brazilian Amazon. Journal of Tropical Ecology, Vol. 2, 173-185, 1989.

[19] S. Saura, S., O. Bodin, M-J. Fortin. Stepping stones are crucial for species long-distance dispersal and range expansion through habitat networks. Journal of Applied Ecology, Vol. 51, 171-182, 2014.

[20] R.T.T. Forman, E.M. Godron. Landscape Ecology. John Wiley \& Sons, New York, 1986.

[21] R.S. Moro, V.M. Nanuncio, K. Dalazoana. A fragmentação natural de uma paisagem em mosaico: Campos Gerais do Paraná, sul do Brasil. In: E. Sánchez Flores, R.E. Díaz Caravantes (eds.). Dinámicas locales del cambio global: aplicaciones de percepción remota y análisis espacial en la evaluación del uso del territorio. UACJ, Ciudad Juarez, 2012.

[22] J.P. Metzger. Estrutura da paisagem e fragmentação: análise bibliográfica, Anais da Academia Brasileira de Ciências, Vol. 71, 445-463, 1999. 